\title{
De vergelijking van werklozen en baanonzekeren naar welzijn en gezond- heid: Een systematisch literatuuroverzicht
}

\author{
Anna K. Schopf \& Hans De Witte ${ }^{1}$
}

In dit artikel wordt nagegaan of werklozen en baanonzekeren van elkaar verschillen inzake hun welzijn en gezondheid. Een overzicht van theorieën suggereert twee mogelijkheden: werkloosheid is problematischer dan baanonzekerheid of beide fenomenen zijn even problematisch voor de gezondheid en het welzijn. Het doel van dit onderzoek is om na te gaan welke mogelijkheid opgaat om zo bij te dragen aan de validering van theorieën (theoretische relevantie) en te bepalen welk fenomeen prioritair beleidsaandacht dient te krijgen (praktische relevantie). Via een systematisch literatuuroverzicht werden tien artikelen geïnventariseerd waaruit met statistische zekerheid conclusies getrokken kunnen worden over de gezondheids- en welzijnsverschillen tussen beide categorieën. De meeste studies suggereren geen verschil met betrekking tot verschillende psychische, lichamelijke, en gedragsmatige welzijns- en gezondheidsreacties tussen werklozen en baanonzekeren. Slechts in enkele studies worden wel verschillen vastgesteld, waarbij soms de baanonzekeren en soms de werklozen een slechtere gezondheid en/of een lager welzijn vertonen. De resultaten zijn dus voornamelijk in overeenstemming met de theoretische stroming die stelt dat werkloosheid en baanonzekerheid even nadelig zijn, omdat beide in dezelfde mate hulpbronnen bedreigen of doen verliezen. We concluderen dat zowel werkloosheid als baanonzekerheid en hun gevolgen gereduceerd dienen te worden en bespreken enkele manieren waarop dit kan worden bereikt.

\section{Inleiding}

Globalisering, toenemende internationale competitie, privatiseringen (vaak gepaard met herstructureringen en 'downsizing'), en periodes van recessie gaven aanleiding tot toenemende flexibilisering van de arbeidsmarkt en verhoging van de tijdelijke tewerkstelling (Hardering \& Bergheim, 2011; Starrin \& Janson, 2006). Deze veranderingen op de arbeidsmarkt hebben geleid tot de observatie dat een tweedeling tussen werkenden en werklozen een te simplistische voorstelling is van de arbeidsmarkt (bv. Maggiori, Johnston, Krings, Massoudi \& Rossier, 2013; Marchand, Drapeau \& Beaulieu-Prevost, 2012). Banen, en de kwaliteit en inhoud ervan, werden onzekerder dan voorheen (Burchell, 1994; Starrin \& Janson, 2006), wat zich vertaalde in een toename van onderzoek naar de welzijns- en gezondheidsgevolgen van baanonzekerheid (De Witte, Vander Elst \& De Cuyper, 2015). Daarnaast deden recessies en herstructureringen

1 Anna Katharina Schopf is verbonden aan de Faculteit Psychologie en Pedagogische Wetenschappen, WOPP/O2L, KU Leuven. Correspondentieadres: KU Leuven, Onderzoekseenheid Arbeids-, Organisatie- en Personeelspsychologie, Dekenstraat 2, bus 3725, B-3000 Leuven, e-mail: katharina.schopf@kuleuven.be. Hans De Witte is verbonden aan dezelfde faculteit en daarnaast ook aan Optentia Research Focus Area, Vanderbijlpark Campus, North-West University, Zuid-Afrika. 
de werkloosheid toenemen, een fenomeen waarvan de negatieve gezondheids- en welzijnsgevolgen eveneens goed gedocumenteerd zijn (McKee-Ryan, Song, Wanberg \& Kinicki, 2005; Paul \& Moser, 2009). Hoewel Kim en von dem Knesebeck (2015) op basis van een literatuuroverzicht geen verschil vonden voor de mentale gezondheid, vonden zij wel dat baanonzekerheid iets sterker samenhangt met somatische symptomen zoals gewrichtspijn of maagproblemen dan werkloosheid, terwijl werkloosheid juist sterker samenhangt met een slechtere algemene gezondheid en mortaliteit dan baanonzekerheid. Dit suggereert dat de gezondheidsgevolgen van baanonzekerheid en werkloosheid verschillend kunnen zijn.

Op het juist vermelde literatuuroverzicht na, werden de gevolgen van beide fenomenen echter zelden met elkaar vergeleken. Deze vergelijking is zowel van belang voor de praktijk en het beleid als voor de wetenschap. In het beleid en de praktijk wordt al jaren gedebatteerd of het nadeliger is om een onzekere baan te hebben dan om werkloos te zijn (De Cort, 2017). Duidelijkheid hierover zou toelaten om beleidsmatig prioriteit te geven aan het bestrijden van een van beide fenomenen. Zo is de vergelijking van de gezondheid en het welzijn van beide fenomenen van belang om gezondheidsuitgaven en interventies te kunnen prioriteren (Mewes, Rief, Martin, Glaesmer \& Brähler, 2013). Volgens een schatting van Goh, Pfeffer en Zenios (2016) zorgen werkloosheid en baanonzekerheid in de VS immers voor bijkomende gezondheidszorgkosten van respectievelijk 15 en 16 miljard US Dollar.

Deze vraag heeft ook theoretische relevantie. Vanuit diverse theorieën kunnen tegenstrijdige voorspellingen gedaan worden over het verschil in welzijn en gezondheid tussen werklozen en baanonzekeren. Terwijl het 'downward spiral' model (Otto \& Dalbert, 2013), het 'latente deprivatie' model (Jahoda, 1981, 1995), en het 'vitamine' model (Warr, 1987) doen vermoeden dat werkloosheid meer nadelige gevolgen heeft dan baanonzekerheid, wijzen het 'equal threat' model, de visie van Lazarus (1966) en Lazarus en Folkman (1984), en de 'agency restriction' theorie (Fryer, 1986; Fryer \& Payne, 1984) erop dat beide fenomenen even nadelig zijn voor de gezondheid en het welzijn. Door middel van een systematisch literatuuroverzicht exploreren we welke van beide visies bevestigd wordt. Hierdoor kunnen de verschillende theorieën ten opzichte van elkaar worden afgewogen en kan verdere theoretische verdieping bereikt worden inzake de gevolgen van werkloosheid en baanonzekerheid. Daarom staat in dit artikel de volgende onderzoeksvraag centraal: '(In hoeverre) verschillen werklozen en baanonzekeren van elkaar met betrekking tot hun gezondheid en welzijn?'.

De gezondheid en het welzijn van werklozen en baanonzekeren wordt vergeleken door middel van een systematisch literatuuroverzicht. Bij een systematisch literatuuroverzicht poogt men een onderzoeksvraag te beantwoorden door alle studies met empirische evidentie samen te brengen die aan bepaalde, vooraf gedefinieerde, criteria voldoen (Green, Higgins, Alderson, Clarke, Mulrow \& Oxman, 2011). Dit laat toe om bevindingen precies en betrouwbaar samen te vatten (Liberati et al., 2009).

Tot nu toe werd één systematisch literatuuroverzicht gepubliceerd waarin de gevolgen van werkloosheid en baanonzekerheid voor beide groepen werden vergeleken (Kim \& von dem Knesebeck, 2015). Sinds dat onderzoek werden echter nieuwe studies gepubliceerd. Bovendien kent het onderzoek van Kim en von dem Knesebeck (2015) beperkingen omdat niet alle opge- 
nomen studies het verschil tussen werklozen en baanonzekeren statistisch toetste en er ook individuen in werden opgenomen die niet op het ogenblik van de bevraging zelf, maar in het verleden werkloos waren geweest.

In dit literatuuroverzicht willen we een striktere literatuurselectie doen en beperken we ons tot studies waarin het verschil tussen werklozen en baanonzekeren expliciet statistisch werd getoetst. De studies worden ook beperkt tot individuen die op het ogenblik van de bevraging zelf werkloos waren. Werkloosheidservaringen in het verleden kunnen immers andere welzijns- en gezondheidsgevolgen hebben dan huidige werkloosheid (bv. Berth, Förster, Balck, Brähler \& Stöbel-Richter, 2008; Burchell, 1994).

In wat volgt gaan we eerst kort in op de bevindingen over werkloosheid en baanonzekerheid die uit de literatuur naar voren komen, en op de theoretische literatuur waarmee de twee fenomenen kunnen worden vergeleken.

\subsection{Bevindingen over werkloosheid en baanonzekerheid}

Voordat we op de associaties van baanonzekerheid en werkloosheid met welzijn en gezondheid ingaan, definiëren we beide fenomenen kort. Baanonzekerheid betekent dat men onzeker is over het voortbestaan van de huidige arbeidsplaats (Sverke, Hellgren \& Näswall, 2002). Deze onzekerheid verwijst naar de ingeschatte kans op het verlies van de baan (cognitieve component) en op de bezorgdheid erover (affectieve component) (De Witte, 2005). We beperken ons tot subjectieve baanonzekerheid, omdat die direct van psychologische en gedragsmatige invloed is op werkenden (Burchell, 1994, 2011). Werklozen worden volgens de Internationale Arbeidsorganisatie (IAO) gedefinieerd als allen die geen baan hebben, voor werk beschikbaar zijn en (actief) naar werk zoeken (RVA, 2018).

Werkloosheid en baanonzekerheid worden in de literatuur geassocieerd met diverse negatieve welzijns- en gezondheidsgevolgen. Daarbij is het echter niet duidelijk of de sterkte van deze associaties dezelfde is voor werklozen en baanonzekeren. Welzijns- en gezondheidsreacties kunnen worden onderverdeeld in psychische, lichamelijke en gedragsmatige reacties (Jex \& Crossley, 2005). Verschillende overzichtsartikelen en meta-analyses documenteren de negatieve gevolgen van werkloosheid met betrekking tot psychische aspecten, waaronder verhoogde angst en depressie en verlaagde zelfwaarde (Paul \& Moser, 2009), verlaagd welzijn (McKeeRyan et al., 2005; Paul \& Moser, 2009), en verlaagde levenstevredenheid (McKee-Ryan et al., 2005). Daarnaast werden ook associaties gevonden tussen werkloosheid en lichamelijke reacties, zoals verlaagde subjectieve en objectieve fysieke gezondheid (McKee-Ryan et al., 2005), meer psychosomatische symptomen (Paul \& Moser, 2009) en hogere mortaliteit (Roelfs, Shor, Davidson \& Schwartz, 2011). Tot slot werden ook negatieve gedragsmatige reacties vastgesteld bij werklozen, zoals alcohol- en drugsmisbruik, roken en medicatiegebruik (Henkel, 2011).

Gelijkaardige associaties worden gerapporteerd voor baanonzekerheid. Voorbeelden van samenhangen tussen baanonzekerheid en psychische reacties zijn verlaagde arbeidstevredenheid (Cheng \& Chan, 2008; De Witte, 1999, 2005; Sverke et al., 2002), verlaagde mentale gezondheid (Cheng \& Chan, 2008; De Witte, 1999; Sverke et al., 2002), verhoogde kans op burn-out, verlaagde levenstevredenheid, meer irritatie en angst (De Witte, 2005). Bovendien hangt baanonzekerheid samen met lichamelijke aspecten, zoals psychosomatische en fysieke klachten (De Witte, 1999, 2005) en de lichamelijke gezondheid (Cheng \& Chan, 2008; Sverke et al., 2002). 
Tot slot worden associaties gevonden tussen baanonzekerheid en gedragsmatige reacties, zoals antidepressiva-gebruik, roken en aantal artsenconsultaties (De Witte et al., 2015). De onderzoeksliteratuur suggereert een causale relatie tussen enerzijds werkloosheid of baanonzekerheid, en gezondheid en welzijn anderzijds (Mewes et al., 2013). Longitudinale evidentie duidt op een negatief effect van werkloosheid op gezondheid en welzijn ('causatie-effect'). Daarnaast doet er zich ook in beperktere mate een 'selectie-effect' voor, omdat een zwakkere gezondheid aanleiding kan geven tot ontslag (Paul \& Moser, 2009). Met betrekking tot baanonzekerheid toont een recent overzicht van longitudinale studies aan dat er ook causale evidentie is dat baanonzekerheid het welzijn reduceert. Een effect in de omgekeerde richting wordt zelden gevonden (De Witte et al., 2016).

\subsection{Theorieën over het belevingsverschil tussen werkloosheid en baanonzekerheid}

Theorieën die de gevolgen van baanonzekerheid en werkloosheid verklaren, kunnen in twee groepen worden verdeeld. Volgens theorieën als het 'downward spiral' model (Otto \& Dalbert, 2013), het 'latente deprivatie' model (Jahoda, 1981, 1995), en het 'vitamine' model (Warr, 1987) heeft werkloosheid meer nadelige gevolgen dan baanonzekerheid. Andere theorieën zoals het 'equal threat' model, de visie van Lazarus (1966) en Lazarus en Folkman (1984), en de 'agency restriction' theorie (Fryer, 1986; Fryer \& Payne, 1984) stellen dat werkloosheid en baanonzekerheid dezelfde (negatieve) gevolgen hebben.

\section{Werkloosheid heeft meer nadelige gevolgen dan baanonzekerheid}

De eerste groep theorieën bestaat uit het 'downward spiral' model (Otto \& Dalbert, 2013), het 'latente deprivatie' model (Jahoda, 1981, 1995), en het 'vitamine' model (Warr, 1987). Deze theorieën delen het inzicht dat werkloosheid tot een grotere frustratie of deprivatie van noden leidt dan baanonzekerheid. Het 'downward spiral' model beschrijft een continuüm van baanzekerheid (start) via baanonzekerheid tot werkloosheid (einde), wat door de auteurs als 'tewerkstellingsonzekerheid' omschreven wordt (Otto \& Dalbert, 2013). De mentale gezondheid neemt in ieder stadium steeds verder af. Het model stelt dat de negatieve gevolgen van deprivatie toenemen met toenemende tewerkstellingsonzekerheid, wat betekent dat werkloosheid, doordat het een hogere tewerkstellingsonzekerheid representeert dan baanonzekerheid, meer gevolgen heeft voor de mentale gezondheid dan baanonzekerheid (Otto \& Dalbert, 2013).

Ook uit het 'latente deprivatie' model van Jahoda $(1981,1995)$ kan worden afgeleid dat werkloosheid meer nadelige gevolgen heeft dan baanonzekerheid. Volgens dit model heeft werk één manifeste functie, namelijk 'geld verdienen', en vijf latente psychologische functies, die gerelateerd zijn aan menselijke basisbehoeftes. De latente functies zijn 'tijdsstructuur', 'uitbreiding van het sociale netwerk', 'link met collectieve doelen en betekenisgeving', 'sociale identiteit en status' en 'regelmatige activiteit'. Doordat de functies niet kunnen worden vervuld wanneer men geen werk heeft, is volgens dit model een baan hebben beter dan werkloos zijn. Omdat iemand die baanonzeker is nog steeds aan het werk is, kunnen we uit het 'latente deprivatie' model afleiden dat werkloosheid problematischer is voor het welzijn en de gezondheid dan baanonzekerheid. 
Het 'vitamine' model van Warr (1987) is een uitbreiding van het 'latente deprivatie' model en beschrijft negen factoren ('vitamines') die het welzijn van zowel werklozen als werkenden beinvloeden. Deze zijn de beschikbaarheid van geld, fysieke veiligheid, een gewaardeerde sociale positie, controlemogelijkheden, vaardigheidsbenutting, extern gegenereerde doelen, afwisseling, een duidelijke en voorspelbare omgeving en mogelijkheden tot interpersoonlijk contact. Met betrekking tot Warr's theorie kan een gelijkaardige redenering gevolgd worden als met betrekking tot Jahoda's model. Bij werkloosheid levert de situatie slechts weinig 'vitamines', terwijl baanonzekerheid slechts gepaard gaat met een reductie in 'duidelijkheid van de omgeving' en 'controlemogelijkheden' (De Witte, 1999). Werkloosheid zou in deze visie dan ook nadeliger zijn voor de gezondheid en het welzijn dan baanonzekerheid.

\section{Werkloosheid en baanonzekerheid zijn in gelijke mate nadelig}

De tweede groep theorieën bestaat uit het 'equal threat' model, de visie van Lazarus (1966) en Lazarus en Folkman (1984), en de 'agency restriction' theorie (Fryer, 1986; Fryer \& Payne, 1984). Volgens deze theorieën hebben werkloosheid en baanonzekerheid dezelfde (mate aan) negatieve gevolgen. Het 'equal threat' model gaat terug op de conservation of resources (COR) theorie (Hobfoll, 1989) en stelt dat werkloosheid en baanonzekerheid even problematisch zijn. Volgens de COR theorie proberen individuen hulpbronnen te verkrijgen, te behouden en te beschermen. Hulpbronnen zijn door het individu gewaardeerde aspecten die een instrumentele en symbolische waarde hebben. Stress ontstaat wanneer men bedreigd wordt met het verlies van een hulpbron, als dit verlies aanwezig is of als men een hulpbron niet heeft kunnen verwerven (Hobfoll, 1989). Het 'equal threat' model past de COR theorie toe door te stellen dat de huidige baan de hulpbron is die in het geval van baanonzekerheid bedreigd wordt, en in het geval van werkloosheid verloren gaat. Daardoor ontstaat stress. Deze is in beide gevallen even sterk omdat de COR theorie niet differentieert tussen de gevolgen van een bedreiging versus het daadwerkelijk verlies van een hulpbron (Otto \& Dalbert, 2013).

Ook de visie van Lazarus (1966) en Lazarus en Folkman (1984) doet vermoeden dat werkloosheid en baanonzekerheid in gelijke mate nadelig zijn. Deze visie stelt dat de anticipatie van een fenomeen even schadelijk is als het daadwerkelijk ervaren van het fenomeen zelf. Deze idee werd door Roskies, Louis-Guerin en Fournier (1993) en De Witte (1999) toegepast op de vergelijking tussen baanonzekerheid en werkloosheid. Baanonzekerheid houdt de anticipatie van werkloosheid in, en heeft volgens deze visie dan ook dezelfde gevolgen voor de gezondheid en het welzijn als werkloos zijn.

Tot slot stelt de 'agency restriction' theorie van Fryer (1986) en Fryer en Payne (1984) dat individuen streven om gebeurtenissen te controleren en in overeenstemming te brengen met de eigen waarden, doelen en verwachtingen. Daardoor kunnen ze actief zin geven aan hun omgeving en deze bepalen, 'personal agency' genoemd (Fryer \& Payne, 1984). Volgens deze theorie zijn de mentale gevolgen van werkloosheid te verklaren door het doorkruisen van de plannen van het individu, en dus door de inperking van hun 'agency', eerder dan door het verlies van het werk op zich. Baanonzekerheid beperkt echter op gelijkaardige wijze de 'agency' van het individu, omdat het eveneens een inperking van de toekomstmogelijkheden inhoudt. Van daaruit kan worden verondersteld dat beide fenomenen (baanonzekerheid en werkloosheid) dezelfde negatieve gevolgen inhouden voor welzijn en gezondheid (Burchell, 1994). 


\section{Besluit}

Er is beperkt onderzoek gedaan naar de validiteit van beide groepen theorieën voor het voorspellen van de gevolgen van baanonzekerheid en werkloosheid. Slechts één studie toetste beide visies ten opzichte van elkaar. Otto en Dalbert (2013) toetsten het 'equal threat' en het 'downward spiral' model binnen één studie en vonden vooral evidentie voor de eerste visie en in mindere mate voor de tweede.

Ook het systematische literatuuronderzoek van Kim en von dem Knesebeck (2015) wijst in deze richting. Zo vonden de auteurs dat werkloosheid en baanonzekerheid even sterk samenhangen met de mentale gezondheid. Terwijl ze daarnaast vonden dat werkloosheid sterker samenhangt met een slechtere algemene gezondheid en mortaliteit dan baanonzekerheid, wat eerder evidentie is voor de 'downward spiral' visie, vonden de auteurs echter ook dat baanonzekerheid iets sterker samenhangt met somatische symptomen dan werkloosheid (Kim \& von dem Knesebeck, 2015).

De vergelijking tussen beide perspectieven staat centraal in het hierna gepresenteerde systematische literatuuronderzoek.

\section{Methode}

Om alle relevante artikelen voor onze vraagstelling in kaart te brengen, werd er een systematische literatuurstudie uitgevoerd. Er werd gefocust op een kwalitatieve integratie van de literatuur: een beschrijving van overkoepelende resultaten over de studies heen. Omwille van het kleine aantal relevante studies en de verschillen tussen de studies met betrekking tot methodieken, steekproeven en onderzochte gezondheids- en welzijnsaspecten, werd geen kwantitatieve integratie (i.e. meta-analyse) uitgevoerd (Liberati et al., 2009).

Het zoeken naar artikelen werd uitgevoerd in Augustus 2016 en aangevuld in Maart 2017. De databanken Web of Science (WoS) en, ter aanvulling, Google Scholar (GS) werden gebruikt. WoS is een veelgebruikte en waardevolle databron ( $\mathrm{Li}$, Rollins \& Yan, 2018). Ondanks kritiek ten opzichten van GS in de literatuur, en de vaststelling dat deze zoekmachine geen geschikt alternatief kan bieden voor databanken als WoS, werd GS als een supplementair zoekinstrument gebruikt omdat het gebruik ervan het aantal gevonden artikelen binnen een zoekopdracht verhoogt (Haddaway, Collins, Coughlin \& Kirk, 2015; Harzing \& Alakangas, 2016). Eén van de tien artikelen die opgenomen werden in de definitieve selectie was niet beschikbaar in WoS, wat het gebruik van GS bijkomend rechtvaardigt.

Om systematisch te werk te gaan en om een duidelijke en transparante rapportering te waarborgen, werden de PRISMA-richtlijnen voor systematische literatuurstudies gevolgd (Liberati et al., 2009). Hierbij werden de relevante artikelen in vier fases geëxtraheerd: identificatie, screening, geschiktheid, en opname. Figuur 1 toont de verschillende fases van de literatuurstudie met telkens de verkregen, overgehouden en uitgesloten artikelen, inclusief redenen en opsplitsingen naar taal. Deze figuur is gebaseerd op de PRISMA-richtlijnen met betrekking tot de rapportering van de informatiestroom (Liberati et al., 2009). 


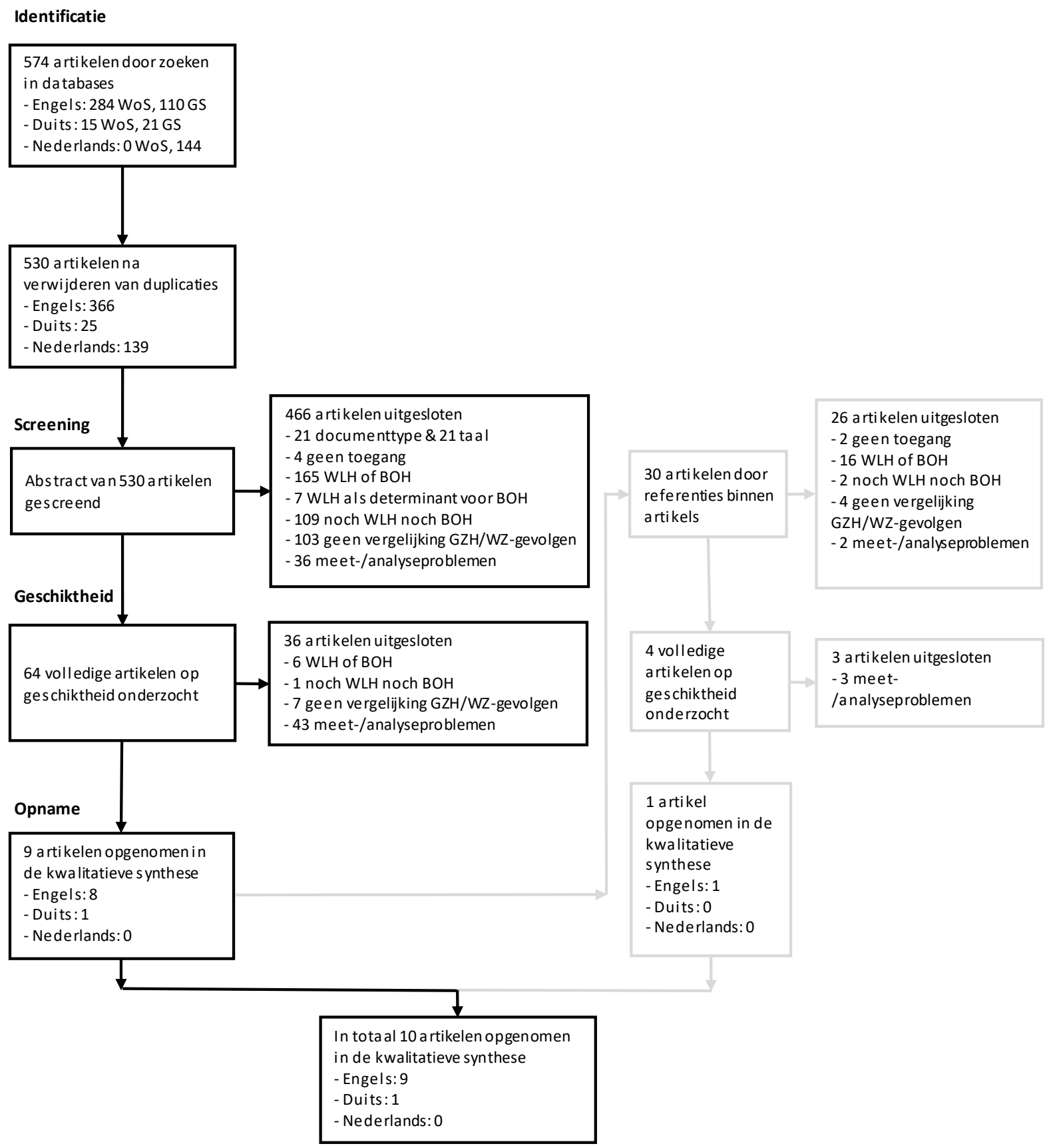

NB: het grijze pad betreft artikelen die bijkomend werden gevonden door de inspectie van referenties binnen gevonden artikelen; gebruikte afkortingen: WoS = Web of Science, GS = Google Scholar; WLH = werkloosheid, $\mathrm{BOH}=$ baanonzekerheid, GZH = gezondheid; WZ = welzijn

\section{Figuur 1 Stroomdiagram van de verschillende fases van de systematische literatuurstudie}

In wat volgt worden de vier verschillende fases overlopen. In de eerste fase, 'identificatie', werden Engelse, Duitse en Nederlandse zoektermen opgesteld en de databanken Web of Science en Google Scholar met deze zoektermen doorzocht. Er werden geen restricties in publicatiedatum gesteld om zoveel mogelijk artikelen te verkrijgen. Er werd telkens gezocht naar een combinatie van trefwoorden over werkloosheid en baanonzekerheid. Deze trefwoorden werden verkregen door de standaardbegrippen te verzamelen, synoniemen en negaties ervan te nemen en literatuurlijsten van overzichtsartikelen over werkloosheid en baanonzekerheid te doorzoeken naar gebruikte termen. De zoekopdracht werd verder gespecifieerd door 'welzijn' of 'ge- 
zondheid' als bijkomende zoektermen op te nemen. Uiteindelijk werden de volgende Engelstalige zoektermen gebruikt binnen de 'Topic'-zoekfunctie van Web of Science: Topic: (unemploy* OR jobseek* OR terminat* OR nonwork OR 'job loss') AND ('job *secur*' OR '*secure employ*' OR 'employment *secur*' OR 'expectations of job loss' OR 'threat of job loss' OR '*secure job*') AND (well-being OR health). Binnen Google Scholar gebruikten we gelijkaardige zoektermen: allintitle: (unemployment OR unemployed OR nonwork OR termination OR 'job loss') ('job security’ OR 'job insecurity’ OR 'insecure job’ OR 'insecure jobs' OR 'employment security' OR 'employment insecurity' OR 'threat of job loss' OR 'insecure employment' OR 'expectations of job loss'). De Duits- en Nederlandstalige zoektermen waren gelijkaardig en kunnen worden opgevraagd bij de eerste auteur. In totaal werden 530 artikelen gevonden; het merendeel Engelstalig.

In de tweede fase, 'screening', werden de abstracts van deze artikelen gelezen om de relevante ervan te kunnen selecteren. Artikelen kwamen in aanmerking als ze aan volgende criteria voldeden: (1) het artikel onderzocht de gezondheid en/of het welzijn van zowel werklozen als baanonzekeren, (2) subjectieve baanonzekerheid en huidige werkloosheid werden onderzocht, (3) de taal van de tekst was Engels, Duits of Nederlands, (4) het artikel werd gepubliceerd in een 'peer reviewed journal'. Artikelen werden uitgesloten wanneer de toegang beperkt was of omwille van meet-/analyseproblemen. Onder deze laatste categorie vielen artikelen die objectieve baanonzekerheid en/of werkloosheidservaringen in het verleden analyseerden (en dus niet voldeden aan criterium 2), artikelen die baanonzekerheid niet afzonderlijk analyseerden, maar als een onderdeel van een ruimere concept (zoals 'kwaliteit van de arbeid'), artikelen die de anticipatie van werkloosheid als één fase van het werkloosheidsproces beschouwden (en dus geen onderscheid maakten tussen baanonzekerheid en werkloosheid), artikelen die het verschil tussen baanonzekeren en werklozen enkel vermelden maar niet statistisch toetsten, en artikelen waarbij de groepen werklozen en baanonzekeren niet rechtstreeks vergeleken worden. Deze laatste categorie bevat dus enkel vergelijkingen van werkenden versus werklozen en/of baanonzekeren versus baanzekeren. Dit resulteerde in 64 artikelen.

Deze werden in de derde fase, 'geschiktheid', grondiger aan de genoemde criteria getoetst. Daarvoor werden de volledige artikelen gelezen. Negen artikelen werden op basis van deze criteria geselecteerd en in de 'kwalitatieve synthese', de integratie van de resultaten, opgenomen (vierde fase, 'opname'). Tot slot werd de referentielijst van de geselecteerde artikelen geinspecteerd om extra relevante artikelen te vinden. Dit resulteerde in één bijkomend artikel. Uiteindelijk werden dus tien artikelen in de kwalitatieve synthese opgenomen. De tien artikelen verwezen naar negen verschillende studies omdat twee artikelen over dezelfde steekproef rapporteerden.

De kwalitatieve synthese omvat het opstellen van een tabel met de belangrijkste informatie van deze studies met telkens een samenvatting van de resultaten (zie Bijlage $1^{\mathrm{i}}$ ). Vervolgens werden welzijns- en gezondheidscategorieën opgesteld op basis van de in de studies onderzochte aspecten en opdelingen uit de literatuur. Er werd gekozen voor een opdeling in drie categorieën: psychische, lichamelijke en gedragsmatige stressreacties (Jex \& Crossley, 2005). De kwalitatieve synthese bevat tevens de beschrijving van de kenmerken van alle geselecteerde studies. Tot slot werden per categorie de resultaten van de diverse studies gerapporteerd. Tevens werd 
aangegeven in hoeverre welzijn/gezondheid van werklozen beter, slechter en even slecht was als het welzijn/de gezondheid van baanonzekeren.

\section{Resultaten}

Zes studies hebben een cross-sectioneel en drie studies een longitudinaal onderzoeksdesign. De studies werden in verschillende Europese landen uitgevoerd (één studie in België, Finland, Noorwegen, Zwitserland en IJsland, en twee studies in Groot-Brittannië en Duitsland). Binnen twee studies werden kortdurig en langdurig werklozen afzonderlijk onderzocht, waarbij de grens tussen beide categorieën op twaalf maanden werd vastgelegd. In drie andere studies waren de personen respectievelijk ongeveer tien maanden, meer dan zes maanden en minder dan tien maanden werkloos en in vier gevallen werd de duur van de werkloosheid niet gespecifieerd. Tabel 1 bevat een samenvatting van de resultaten. De resultaten zijn weergegeven per categorie van stressreacties, waarin de welzijns- en gezondheidsgevolgen kunnen worden ingedeeld: psychische, lichamelijke, en gedragsmatige stressreacties (Jex \& Crossley, 2005). 
Tabel 1 Samenvattende tabel met de resultaten van het literatuuroverzicht

\begin{tabular}{|c|c|c|c|}
\hline Categorie & Referentie & Afhankelijke variabele & Resultaten \\
\hline \multirow{15}{*}{$\begin{array}{l}\text { Psychische } \\
\text { reacties }\end{array}$} & De Witte, 1999 & Welzijn (GHQ) & $\mathrm{ns}$ \\
\hline & Ferrie et al., 2001 & Welzijn (GHQ) & ns \\
\hline & $\begin{array}{l}\text { Flint, Bartley et } \\
\text { al., 2013; }\end{array}$ & Welzijn (GHQ) & $\begin{array}{l}\text { Werklozen hebben een lager welzijn dan baanonze- } \\
\text { keren }\end{array}$ \\
\hline & $\begin{array}{l}\text { Flint, Shelton et } \\
\text { al., } 2013\end{array}$ & & \\
\hline & \multirow[t]{2}{*}{ Griep et al., 2016} & Psychologische klachten & $\begin{array}{l}\text { Baanonzekeren hebben even veel klachten als lang- } \\
\text { durig werklozen en meer klachten dan kortdurig } \\
\text { werklozen }\end{array}$ \\
\hline & & Levenstevredenheid & $\begin{array}{l}\text { Lang- en kortdurig werklozen hebben een lagere le- } \\
\text { venstevredenheid dan baanonzekeren }\end{array}$ \\
\hline & Halvorsen, 1998 & $\begin{array}{l}\text { Psychisch onwelzijn (de- } \\
\text { pressie en angst) }\end{array}$ & ns \\
\hline & \multirow{2}{*}{$\begin{array}{l}\text { Maggiori et al., } \\
2013\end{array}$} & Welzijn (GHQ) & ns \\
\hline & & Levenstevredenheid & $\begin{array}{l}\text { Werklozen hebben een lagere levenstevredenheid } \\
\text { dan baanonzekeren }\end{array}$ \\
\hline & \multirow{2}{*}{$\begin{array}{l}\text { Mewes et al., } \\
2013\end{array}$} & Depressieve symptomen & ns \\
\hline & & Angstsymptomen & ns \\
\hline & \multirow{2}{*}{$\begin{array}{l}\text { Otto \& Dalbert, } \\
2013\end{array}$} & Levenstevredenheid & ns \\
\hline & & Zelfwaarde & ns \\
\hline & \multirow[t]{2}{*}{$\begin{array}{l}\text { Snorradottir et } \\
\text { al., } 2015\end{array}$} & Positief welzijn & $\begin{array}{l}\text { Werkloze mannen en vrouwen hebben een hoger } \\
\text { positief welzijn dan baanonzekere mannen en vrou- } \\
\text { wen }\end{array}$ \\
\hline & & $\begin{array}{l}\text { Mentaal onwelzijn } \\
\text { (mentale symptomen) }\end{array}$ & $\begin{array}{l}\text { Werkloze mannen en vrouwen ervaren minder men- } \\
\text { taal onwelzijn (minder mentale symptomen) dan } \\
\text { baanonzekere mannen en vrouwen }\end{array}$ \\
\hline \multirow{8}{*}{$\begin{array}{l}\text { Lichame- } \\
\text { lijke reac- } \\
\text { ties }\end{array}$} & \multirow[t]{4}{*}{ Ferrie et al., 2001} & $\begin{array}{l}\text { Gemiddelde of slechte } \\
\text { gezondheid }\end{array}$ & ns \\
\hline & & Langdurige ziekte & ns \\
\hline & & Klachten & ns \\
\hline & & Gezondheidsproblemen & ns \\
\hline & \multirow[t]{2}{*}{ Griep et al., 2016} & Lichamelijke klachten & ns \\
\hline & & $\begin{array}{l}\text { Zelfbeoordeelde ge- } \\
\text { zondheid }\end{array}$ & ns \\
\hline & $\begin{array}{l}\text { Mewes et al., } \\
2013\end{array}$ & $\begin{array}{l}\text { Somatoforme sympto- } \\
\text { men }\end{array}$ & $\mathrm{ns}$ \\
\hline & $\begin{array}{l}\text { Snorradottir et } \\
\text { al., } 2015\end{array}$ & Somatische symptomen & $\begin{array}{l}\text { Werkloze vrouwen en mannen hebben minder so- } \\
\text { matische symptomen dan baanonzekere vrouwen en } \\
\text { mannen }\end{array}$ \\
\hline \multirow{5}{*}{$\begin{array}{l}\text { Gedragsma- } \\
\text { tige reacties }\end{array}$} & \multirow[t]{4}{*}{ Ferrie et al., 2001} & Alcoholmisbruik & ns \\
\hline & & Rookgedrag & ns \\
\hline & & Lichamelijke beweging & $\begin{array}{l}\text { Werklozen doen meer aan lichamelijke beweging } \\
\text { dan baanonzekeren }\end{array}$ \\
\hline & & $\begin{array}{l}\geq 4 \text { consultaties van art- } \\
\text { sen in de voorbije } 12 \\
\text { maanden }\end{array}$ & ns \\
\hline & $\begin{array}{l}\text { Mewes et al., } \\
2013\end{array}$ & $\begin{array}{l}\text { Aantal consultaties van } \\
\text { artsen in de voorbije } 12 \\
\text { maanden }\end{array}$ & ns \\
\hline
\end{tabular}

NB: $n s=$ het verschil tussen werklozen en baanonzekeren is niet statistisch significant 


\subsection{Psychische reacties}

Alle studies uit dit literatuuroverzicht onderzochten psychische reacties. Daarvan onderzochten acht studies mentale klachten in het algemeen of meer specifiek angst- en/of depressiesymptomen. Meerdere studies onderzochten de mentale gezondheid via de 'General Health Questionnaire' (GHQ), waarbij een hogere score een slechtere mentale gezondheid indiceert (Goldberg, 1978). Een alternatieve manier om naar psychische reacties te kijken is om positieve aspecten van mentaal welzijn te analyseren, zoals de levenstevredenheid. Dit gebeurde in drie studies. Eén van deze studies onderzocht eveneens de zelfwaarde, terwijl een vierde studie positief welzijn mat met een afzonderlijke schaal.

Zes van de negen studies die psychische reacties onderzochten vonden geen verschillen tussen werklozen en baanonzekeren. De Witte (1999), Ferrie en collega's (2001) en Maggiori en collega's (2013) stelden geen significante verschillen vast tussen de GHQ-scores van beide groepen. Halvorsen (1998) onderzocht angst en depressie bij personen die (na langdurige werkloosheid) opnieuw werk hadden gevonden of nog steeds werkloos waren. Hij vond geen verschil tussen werklozen en baanonzekeren wat hun gemiddelde angst- en depressiescores en de verdeling van de scores betrof. Ook Mewes en collega's (2013) vonden geen significante verschillen tussen beide groepen wat angst- of depressiesymptomen betreft. Griep en collega's (2016) vonden in een vergelijking tussen baanonzekere werknemers met een contract van onbepaalde duur en langdurig werklozen geen verschil inzake mentale klachten. Tot slot vonden Otto en Dalbert (2013) geen significante verschillen tussen de levenstevredenheid of de zelfwaarde van baanonzekeren en werklozen.

Drie studies vonden dat werklozen een slechtere mentale gezondheid rapporteerden dan baanonzekeren. Flint en collega's (Flint, Bartley, Shelton \& Sacker, 2013; Flint, Shelton, Bartley \& Sacker, 2013) vonden dat werklozen een hogere score op de GHQ, en dus een lager welzijn, vertoonden dan baanonzekeren. Bovendien stelden ze positieve effecten voor de mentale gezondheid vast bij een transitie van werkloosheid naar baanonzekerheid en negatieve effecten bij een omgekeerde transitie (Flint, Bartley, et al., 2013). Griep en collega's (2016) vonden dat kort- en langdurig werklozen significant lager scoorden op levenstevredenheid dan baanonzekeren. Ook Maggiori en collega's (2013) vonden dat werklozen hun levenstevredenheid als significant beter beoordeelden dan baanonzekeren.

Tot slot waren er twee studies waarin baanonzekeren (gedeeltelijk) een lager mentaal welzijn vertoonden dan werklozen. Griep en collega's (2016) vonden dat baanonzekeren significant meer subjectieve mentale klachten rapporteerden dan kortdurig werklozen. Snorradottir, Tomasson, Vilhjalmsson en Rafnsdottir (2015) onderzochten voormalige werknemers van drie grote IJslandse banken die getroffen waren door de economische crisis. Ze vergeleken baanonzekere 'blijvers' (werknemers die mochten blijven werken) met 'vertrekkers' (werknemers die hun baan kwijt speelden). Inzake mentaal welzijn, gemeten met een positieve schaal ('positief mentaal welzijn') en een negatieve schaal ('mentaal onwelzijn', met onder andere een peiling naar depressie- en angstsymptomen) scoorden baanonzekeren significant slechter dan werklozen.

Alles bij elkaar genomen suggereren de meeste studies dat er zich geen verschil voordoet tussen werklozen en baanonzekere werkenden wat psychische reacties betreft. Daarnaast suggereert 
een minderheid van de studies dat er zich wél een verschil voordoet. Daarbij geven haast evenveel studies aan dat baanonzekeren een lager mentaal welzijn vertonen in vergelijking tot studies die aangeven dat werklozen een lager mentaal welzijn vertonen.

\subsection{Lichamelijke reacties}

Studies die de zelfbeoordeelde gezondheid, de fysieke gezondheid of fysieke klachten, ziektes en mortaliteit onderzochten worden hier samengenomen onder de categorie 'lichamelijke reacties'. De resultaten liggen over het algemeen in dezelfde lijn. Van de vier studies die lichamelijke reacties onderzochten, vonden drie geen verschillen tussen werklozen en baanonzekeren. De toets van Griep en collega's (2016) leverde geen significante verschillen op tussen werklozen en baanonzekeren wat betreft lichamelijke gezondheidsklachten en zelfbeoordeelde gezondheid. Ferrie en collega's (2001) vonden geen verschillen met betrekking tot zelfbeoordeelde gezondheid, langdurige ziektes, klachten of gezondheidsproblemen. Mewes en collega's (2013) vonden geen significant verschil tussen baanonzekeren en werklozen wat betreft somatoforme symptomen; lichamelijke symptomen die niet door een medische oorzaak te verklaren zijn (Mewes et al., 2013).

Snorradottir et al. (2015) vonden in hun studie als enigen dat baanonzekerheid met méér lichamelijke problemen gepaard gaat. De werklozen (afgedankten) rapporteerden immers significant minder somatische symptomen dan de baanonzekere 'blijvers'.

Het aantal studies waarin lichamelijke reacties vergeleken werden is dus vrij beperkt. Globaal genomen lijken werklozen en baanonzekeren niet te verschillen inzake aspecten van hun lichamelijke gezondheid.

\subsection{Gedragsmatige reacties}

Slechts twee studies hadden betrekking op gedragsmatige reacties. Over het algemeen werden daarbij evenmin verschillen gevonden tussen werklozen en baanonzekeren. Ferrie en collega's (2001) vonden geen significant verschil tussen baanonzekeren en werklozen wat betreft hun rookgedrag en alcoholconsumptie. Bovendien vonden noch Ferrie et al. (2001) noch Mewes et al. (2013) verschillen voor wat betreft de hoeveelheid consultaties van artsen. In de studie van Ferrie et al. (2001) rapporteerden baanonzekeren wel dat ze significant minder intens lichamelijk bewegen dan werklozen. Samenvattend lijken werklozen en baanonzekeren gelijkaardige gedragsmatige reacties te vertonen, op het aspect lichamelijke beweging na, waarbij baanonzekeren lager lijken te scoren.

\section{Discussie}

Het doel van deze studie was het in kaart brengen van eventuele verschillen in gezondheid en welzijn van baanonzekeren versus werklozen. We rapporteerden de resultaten van een systematisch literatuuroverzicht. Daaruit blijkt allereerst dat er relatief weinig studies werden uitgevoerd die de gezondheid en het welzijn van werklozen en baanonzekeren op rechtstreekse wijze vergelijken. De vergelijking tussen de studies die in dit artikel werden opgenomen met deze uit het literatuuroverzicht van Kim en von dem Knesebeck (2015) toont aan dat de overlap erg 
beperkt is: slechts drie studies komen overeen tussen beide literatuuroverzichten. Dit toont de complementariteit van deze nieuwe literatuurstudie aan.

De meerderheid van de studies uit ons literatuuroverzicht suggereert dat beide groepen niet van elkaar verschillen. Dit is in overeenstemming met de theoretische stroming rond het 'equal threat' model (Otto \& Dalbert, 2013). Daarin wordt gesteld dat werkloosheid en baanonzekerheid even bedreigend zijn, omdat ze in dezelfde mate hulpbronnen bedreigen of verloren laten gaan (Hobfoll, 1989; Otto \& Dalbert, 2013), of omdat beide fenomenen de 'personal agency' van het individu bedreigen (Fryer \& Payne, 1984). Deze vaststellingen sluiten ook goed aan bij de stelling van Lazarus en Folkman (1984) dat de anticipatie van een fenomeen even schadelijk kan zijn voor het individu als het daadwerkelijk meemaken ervan.

Toch leveren niet alle studies dezelfde conclusie op. In een minderheid van de studies werd vastgesteld dat werkloosheid méér belastend is dan baanonzekerheid. Twee van deze drie studies hebben betrekking op de levenstevredenheid, en één op het mentale welzijn zoals dat gemeten kan worden met de GHQ. De resultaten van deze studies liggen in de lijn van het 'downward spiral' model (Otto \& Dalbert, 2013), dat suggereert dat de negatieve gevolgen van deprivatie stijgen van baanonzekerheid (gedeeltelijke deprivatie) naar werkloosheid (volledige deprivatie). Werkloosheid depriveert het individu van alle functies van werk (Jahoda, 1981) of van alle 'arbeidsvitamines' uit Warr's 'vitamine'-model (Warr, 1987), terwijl dat bij baanonzekerheid slechts ten dele het geval is. De termijn waarin de gevolgen worden gemeten bleek een invloed uit te oefenen op de vaststelling dat werkloosheid meer belastend is dan baanonzekerheid. Zo vonden Griep en collega's (2016) dat baanonzekeren evenveel psychologische klachten rapporteerden als langdurige werklozen, maar méér dan kortdurig werklozen. De grens tussen beide groepen lag bij 12 maanden.

Tot slot suggereert een andere minderheid van studies dat baanonzekerheid méér belastend is voor het welzijn en de gezondheid. Een theoretische visie die baanonzekerheid meer nadelige gevolgen toeschrijft dan werkloosheid kon in de literatuur niet worden gevonden. Opvallend is dat haast alle evidentie voor deze laatste conclusie afkomstig is uit één studie (Snorradottir et al., 2015). Deze studie werd uitgevoerd in IJsland in de bankensector, die sterk te lijden had onder de recentste economische crisis. In deze studie werden afgedankte werknemers uit de bankensector vergeleken met werknemers die de crisis hadden 'overleefd' ('blijvers'). De resultaten van deze studie suggereren dat het belangrijk kan zijn om rekening te houden met de specifieke context van de respondenten. Het verlies van een specifieke baan in een specifieke sector en omwille van specifieke omstandigheden (economische recessie) heeft in de IJslandse studie resultaten tot gevolg die afwijken van de resultaten die in de meeste overige studies worden vastgesteld. Zo is het mogelijk dat door de plotse verandering van de bankenstatus en reputatie de stress van de 'blijvers' en de opluchting van de afgedankte werknemers toenamen (Snorradottir et al., 2015). Een alternatieve verklaring kan zijn dat er reeds vóór de crisis relevante verschillen waren tussen de blijvers en de later afgedankte werknemers (selectie-effect). Het cross-sectionele design van de studie laat niet toe om hier uitsluitsel over te geven. 


\subsection{Beperkingen en suggesties voor toekomstig onderzoek}

De bevinding dat er zich in de meeste studies geen verschil in welzijn en gezondheid voordoet tussen werklozen en baanonzekeren, dient verder genuanceerd te worden. Het al dan niet vaststellen van een verschil kan immers door andere variabelen en onderzoeksbeperkingen worden beïnvloed.

Een eerste beperking van dit literatuuroverzicht is dat er slechts weinig empirische studies werden uitgevoerd. Uitspraken over bijvoorbeeld lichamelijke en gedragsmatige reacties dienen voorzichtig te worden geïnterpreteerd, omdat ze slechts betrekking hebben op respectievelijk vier en twee studies. Meer vergelijkend onderzoek lijkt dan ook aangewezen in de toekomst. In deze literatuurstudie werden empirische studies uit uiteenlopende contexten met elkaar vergeleken. De afwijkende resultaten in de IJslandse bankensector in IJsland doet vermoeden dat de context van de studie de resultaten heeft beïnvloed. Deze elementen van de context dienen dan ook onder controle te worden gehouden in toekomstig onderzoek. Een ander relevant contextgegeven betreft de arbeidsomstandigheden van de werkenden. Zo lijken baanonzekeren met een lage taakautonomie en weinig leermogelijkheden een lager welzijn en een lagere gezondheid te hebben dan baanonzekeren met een hoge taakautonomie en veel leermogelijkheden (Starrin \& Janson, 2006). Dit kan op zijn beurt de vergelijking tussen baanonzekeren en werklozen beïnvloeden. Ook het land en het jaar van bevraging kunnen een invloed hebben. Zo vonden Kim en von dem Knesebeck (2016) in hun meta-analyse de grootste effecten voor baanonzekerheid en werkloosheid in Europese studies en de zwakste in studies uit de VS. Paul en Moser (2009) vonden dat de gevolgen van werkloosheid minder erg zijn in landen die economisch het meest ontwikkeld zijn en een grote inkomensgelijkheid en een sterke ontslagbescherming hebben dan in landen die, in vergelijking, economisch minder ontwikkeld zijn en een kleinere inkomensgelijkheid en een zwakkere ontslagbescherming hebben. Sjöberg (2010) vond dat hoge werkloosheidsuitkeringen samengingen met een stijgend welzijn voor zowel werklozen als individuen met een kwetsbare positie op de arbeidsmarkt. Het is dus belangrijk om in toekomstig onderzoek voor factoren zoals de arbeidsomstandigheden van de baanonzekeren, het land en het jaar van de bevraging of de mate van sociale zekerheid te controleren. De door deze literatuurstudie in kaart gebrachte empirische studies werden voornamelijk uitgevoerd in Westerse landen. Dit beperkt de veralgemeenbaarheid van de gerapporteerde vaststellingen. Bijgevolg suggereren we onderzoek in niet-Westerse landen om de generaliseerbaarheid van de bevindingen te testen.

Een andere beperking van dit onderzoek is dat de samenhangen in de meeste studies enkel cross-sectioneel werden onderzocht. Hoewel de literatuur hoofdzakelijk 'causatie-effecten' van werkloosheid en baanonzekerheid op welzijn en gezondheid vaststelt, doet er zich soms ook omgekeerde causaliteit voor ('selectie'). Hier geen rekening mee houden kan de resultaten vertekenen. Onderzoek suggereert immers dat de effecten van baanonzekerheid groter worden indien voor omgekeerde causaliteit wordt gecontroleerd (Geishecker, 2012), terwijl de effecten van werkloosheid in dat geval kleiner worden (Kim \& von dem Knesebeck, 2016; Kroll \& Lampert, 2012). De conclusie dat werklozen en baanonzekeren niet van elkaar lijken te verschillen, kan daardoor beïnvloed zijn. Er is dus behoefte aan verder longitudinaal onderzoek en het controleren voor het gezondheids- en welzijnsniveau in het verleden. 
Een derde beperking van deze literatuurstudie is dat enkel gezondheids- en welzijnsaspecten onderzocht worden. Het is interessant om ook een ruimer scala aan uitkomstvariabelen te vergelijken, zoals de gevolgen voor de gezinnen van werklozen en baanonzekeren. Het onderzoeksdesign van alle studies was tevens kwantitatief van aard. Het in de toekomst uitvoeren van kwalitatief onderzoek kan interessant zijn om de beleving van beide fenomenen op rijkere wijze te exploreren en te vergelijken (Büssing, 1987).

In de gerapporteerde studies worden enkel globale verschillen tussen werklozen en baanonzekeren onderzocht. Interindividuele verschillen die de ernst van werkloosheid of baanonzekerheid kunnen versterken, zoals de persoonlijkheid (Roskies et al., 1993) en het coping gedrag, werden niet bestudeerd (Hobfoll, 1989). Toekomstige studies kunnen deze interindividuele verschillen onderzoeken en nagaan hoe de vergelijking van baanonzekeren en werklozen erdoor wordt beïnvloed. Tevens kan worden nagegaan of deze interindividuele verschillen een zelfde effect hebben in beide categorieën.

Ook werd de duur van de werkloosheid in vele studies niet gespecifieerd, hoewel deze de sterkte van de gevolgen kan beïnvloeden (Büssing, 1987; Griep et al., 2016). Hetzelfde kan gelden voor de duur van de baanonzekerheid, en voor de ervaren intensiteit ervan. Het is dus belangrijk deze aspecten als moderatoren op te nemen in toekomstig onderzoek, om de invloed ervan in kaart te brengen.

Een andere kanttekening is dat deze studie zich beperkt tot een kwalitatieve synthese van de literatuur. Er werd geen meta-analyse uitgevoerd. Een dergelijke meta-analyse vormt een waardevolle toekomstige uitbreiding. Ze zou een statistische toets toelaten met betrekking tot onze onderzoeksvraag en informatie geven over de grootte van het eventuele verschil in welzijn en gezondheid tussen werklozen en baanonzekeren.

Het is steeds mogelijk dat enkele relevante artikelen niet in dit literatuuroverzicht werden opgenomen. Om de volledigheid van de selectie te verhogen hebben we de resultaten van onze hoofd-databron Web of Science aangevuld met Google Scholar en werden de referentielijsten van de geselecteerde artikelen geïnspecteerd om additionele artikelen te vinden. Het kan evenwel zinvol zijn om in de toekomst bijkomende bibliografische databanken te consulteren, zoals Scopus (Harzing \& Alakangas, 2016).

De resultaten liggen vooral in lijn van theorieën die géén verschil in gezondheid en welzijn voorspellen tussen werklozen en baanonzekeren. Dat zijn het 'equal threat' model (Otto \& Dalbert, 2013), de 'agency restriction' theorie (Fryer \& Payne, 1984) en de visie van Lazarus en Folkman (1984). Welk achterliggend proces het ontbreken van het verschil het best verklaart kan uit dit literatuuroverzicht echter niet worden afgeleid. Is werkloosheid even problematisch als baanonzekerheid omdat beide fenomenen in dezelfde mate hulpbronnen bedreigen of verloren laten gaan (Hobfoll, 1989; Otto \& Dalbert, 2013), omdat beide fenomenen de 'personal agency' van het individu bedreigen (Fryer \& Payne, 1984), of omdat de anticipatie van een fenomeen even schadelijk kan zijn als het daadwerkelijk meemaken ervan (Fryer \& Payne, 1984)? Het is daarom zinvol om de specifieke onderliggende theorieën verder te operationaliseren en te toetsen in toekomstig onderzoek. 


\subsection{Praktische implicaties en interventies}

Werklozen en baanonzekeren lijken over het algemeen een gelijkaardige verlaging van hun welzijn en gezondheid te ervaren. De belangrijkste praktische implicatie is dan ook dat werkloosheid en baanonzekerheid in gelijke mate dienen te worden vermeden. Daarom suggereren we interventies die volgens andere studies op beide fenomenen van toepassing zijn.

Met betrekking tot primaire preventie is het reduceren van werkloosheid de meest urgente interventie (Hardering \& Bergheim, 2011; Warr, 1987). Naast het directe effect ervan op het aantal werklozen, heeft het ook een positief effect voor baanonzekeren, omdat een lagere werkloosheidsgraad gepaard gaat met een vermindering van de subjectieve baanonzekerheid (Schwarz, 2012). Bovendien komt baanonzekerheid vaker voor bij mensen die voordien werkloos waren (Burchell, 1994), waardoor een verlaging van de werkloosheid tevens de perceptie van baanonzekerheid in de toekomst reduceert. Ook een strikte(re) ontslagbescherming beperkt het aantal ontslagen én reduceert subjectieve baanonzekerheid (Hipp, 2016).

Als secundaire preventie kan de financiële situatie van werklozen verbeterd worden, door bijvoorbeeld de werkloosheidsuitkeringen te verhogen (Warr, 1987). Dit kan baanonzekerheid minder bedreigend maken. Het welzijn van zowel werklozen als baanonzekeren kan daardoor verbeteren. Bovendien vond Hipp (2016) dat hogere werkloosheidsuitkeringen samengaan met minder baanonzekerheid. De toegankelijkheid tot trainingen verbeteren kan de 'vitamines' autonomie, vaardigheidsbenutting, afwisseling en sociale contacten van werklozen verhogen, wat de negatieve gevolgen van werkloosheid kan afzwakken (Warr, 1987). Trainingen reduceren tevens de baanonzekerheid van werknemers (Parent-Thirion et al., 2016). Daarnaast wordt de gepercipieerde inzetbaarheid over het algemeen positief beïnvloed door het volgen van trainingen. Gepercipieerde inzetbaarheid verlaagt de perceptie van baanonzekerheid en reduceert tevens de negatieve gevolgen van zowel baanonzekerheid als werkloosheid (Green, 2011; Otterbach \& Sousa-Poza, 2016).

Belangrijk is ook om factoren te identificeren die de veerkracht vergroten, waardoor deze aan minder veerkrachtige individuen kunnen worden aangeleerd (Roskies et al., 1993). Het verhogen van de 'career adaptability' hoort hiertoe. Dit is de bekwaamheid om zich aan nieuwe omstandigheden over de eigen loopbaan aan te passen (Koen, Klehe, Van Vianen, Zikic \& Nauta; 2010). 'Career adaptability' hangt samen met een hoger welzijn en zwakt de negatieve gevolgen van baanonzekerheid op het welzijn af (Maggiori et al., 2013). Voor werklozen hangt deze variabele bovendien samen met het vinden van kwaliteitsvoller werk in de toekomst (Koen et al., 2010).

Er moet ook curatief voor de betroffen individuen gezorgd worden. Mewes et al. (2013) pleiten voor een aangepaste mentale gezondheidsverlening voor zowel werklozen als baanonzekeren om het onwelzijn bij individuen en de resulterende gezondheidsgerelateerde kosten te verlagen. Onderzoek suggereert dat velen de behoefte ervaren, maar onvoldoende geïnformeerd zijn over mogelijke interventies (Berth et al., 2008). Daarom dient het aanwezige aanbod aan interventies goed gecommuniceerd te worden aan zowel baanonzekeren als werklozen.

Samenvattend lijken werkloosheid en baanonzekerheid een vergelijkbare belasting te vormen voor het welzijn en de gezondheid van de betrokkenen. Deze conclusie ligt in de lijn van het 
'equal threat' model. Aan één van beide fenomenen prioriteit geven lijkt dus niet gerechtvaardigd: beide fenomenen én hun gevolgen dienen in gelijke mate bestreden te worden. Beide fenomenen hangen ook samen en de bestrijding ervan dient wellicht eveneens in samenhang te gebeuren.

\section{Praktijkbox}

Wat betekenen de resultaten voor de praktijk?

- Werkloosheid en baanonzekerheid gaan in ongeveer dezelfde mate samen met een verlaging van de gezondheid en het welzijn van de betrokkenen. Daarom dienen beide fenomenen én hun gevolgen vermeden of beperkt te worden. Dit kan op twee wijzen: door structureel in te grijpen, en door trainingen aan te bieden.

- Structureel kan gewerkt worden aan het beperken van de werkloosheid, door in te zetten op een actief arbeidsmarktbeleid dat baancreatie beoogt. Ook het uitbreiden van de ontslagbescherming en de verhoging van de werkloosheidsuitkeringen lijken aangewezen. Deze structurele interventies reduceren het aantal werklozen én de subjectieve baanonzekerheid, en verlichten tevens de negatieve beleving van beide fenomenen.

- Daarnaast kunnen ook trainingen worden uitgewerkt en aangeboden aan werklozen en baanonzekeren, met het oog op het verhogen van hun veerkracht, gepercipieerde inzetbaarheid én 'career adaptability'.

\footnotetext{
${ }^{\text {i }}$ Een meer uitgebreide tabel met bijkomende informatie over de meting, het jaar van onderzoek en de operationalisatie van baanonzekerheid kan bij de eerste auteur worden opgevraagd.
} 


\section{Literatuurii}

Berth, H., Förster, P., Balck, F., Brähler, E., \& Stöbel-Richter, Y. (2008).

Arbeitslosigkeitserfahrungen, Arbeitsplatzunsicherheit und der Bedarf an psychosozialer Versorgung [Unemployment, job insecurity and the need for psychosocial support]. Gesundheitswesen, 70, 289-294. doi:10.1055/s-2008-1065363

Burchell, B. (1994). The effects of labour market position, job insecurity, and unemployment on psychological health. In D. Gallie, C. Marsh, \& C. Vogler (Eds.), Social Change and the Experience of Unemployment (pp. 188-212). Oxford, England: Oxford University Press.

Burchell, B. (2011). A temporal comparison of the effects of unemployment and job insecurity on wellbeing. Sociological Research Online, 16(1), 1-13. doi:10.5153/sro.2277

Büssing, A. (1987). Arbeitsplatzunsicherheit und Antizipation von Arbeitslosigkeit als Stadien des Arbeitslosigkeitsprozesses. Soziale Welt, 38, 309-329. Gedownload van www.jstor.org/stable/40877513

Cheng, G.H.L., \& Chan, D.K.S. (2008). Who suffers more from job insecurity? A metaanalytic review. Applied Psychology: An International Review, 57, 272-303. doi:10.1111/j.1464-0597.2007.00312.x

De Cort, G. (2017, 19 mei). 'Beter een precaire job dan geen job'. De Standaard.

*De Witte, H. (1999). Job insecurity and psychological well-being: Review of the literature and exploration of some unresolved issues. European Journal of Work and Organizational psychology, 8, 155-177. doi:10.1080/135943299398302

De Witte, H. (2005). Job insecurity: Review of the international literature on definitions, prevalence, antecedents and consequences. SA Journal of Industrial Psychology, 31(4), 16. doi:10.4102/sajip.v31i4.200

De Witte, H., Vander Elst, T., \& De Cuyper, N. (2015). Job insecurity, health and well-being. In J. Vuori, R. Blonk, \& R.H. Price (Eds.), Sustainable Working Lives: Managing Work Transitions and Health Throughout the Life Course. New York: Springer, pp. 109-128.

De Witte, H., Pienaar, J., \& De Cuyper, N. (2016). Review of 30 years of longitudinal studies on the association between job insecurity and health and well-being. Is there causal evidence? Australian Psychologist, 51(1), 18-31. DOI:10.1111/ap.12176

*Ferrie, J.E., Martikainen, P., Shipley, M.J., Marmot, M.G., Stansfeld, S.A., \& Smith, G.D. (2001). Employment status and health after privatisation in white collar civil servants: Prospective cohort study. British Medical Journal, 322, 1-7. doi:10.1136/bmj.322.7287.647

*Flint, E., Bartley, M., Shelton, N., \& Sacker, A. (2013). Do labour market status transitions predict changes in psychological well-being? Journal of Epidemiology and Community Health, 67, 796-802. doi:10.1136/jech-2013-202425

*Flint, E., Shelton, N., Bartley, M., \& Sacker, A. (2013). Do local unemployment rates modify the effect of individual labour market status on psychological distress? Health \& Place, 23, 1-8. doi:10.1016/j.healthplace.2013.04.004

Fryer, D. (1986). Employment deprivation and personal agency during unemployment: A critical discussion of Jahoda's explanation of the psychological effects of unemployment. Social Behaviour 1(1), 3-23.

Fryer, D., \& Payne, R. (1984). Proactive behaviour in unemployment: Findings and implications. Leisure studies, 3(3), 273-295. doi:10.1080/02614368400390231

Geishecker, I. (2012). Simultaneity bias in the analysis of perceived job insecurity and subjective well-being. Economics Letters, 116, 319-321.

doi:10.1016/j.econlet.2012.03.018 
Goh, J., Pfeffer, J., \& Zenios, S.A. (2016). The relationship between workplace stressors and mortality and health costs in the United States. Management Science, 62, 608-628. doi:10.1287/mnsc.2014.2115

Goldberg, D. (1978). Manual of the general health questionnaire. Windsor: National Foundation for Educational Research.

Green, F. (2011). Unpacking the misery multiplier: How employability modifies the impacts of unemployment and job insecurity on life satisfaction and mental health. Journal of Health Economics, 30, 265-276. doi:10.1016/j.jhealeco.2010.12.005

Green, S., Higgins, J. P., Alderson, P., Clarke, M., Mulrow, C. D., Oxman, \& D, A. (2011). Introduction. In J. P. T. Higgins \& S. Green (Eds.), Cochrane handbook for systematic reviews of interventions (Vol. 5.1.0): The Cochrane Collaboration. Retrieved from http://handbook.cochrane.org/

*Griep, Y., Kinnunen, U., Natti, J., De Cuyper, N., Mauno, S., Makikangas, A., \& De Witte, H. (2016). The effects of unemployment and perceived job insecurity: A comparison of their association with psychological and somatic complaints, self-rated health and life satisfaction. International Archives of Occupational and Environmental Health, 89, 147162. doi:10.1007/s00420-015-1059-5

Haddaway, N.R., Collins, A.M., Coughlin, D., \& Kirk, S. (2015). The role of Google Scholar in evidence reviews and its applicability to grey literature searching. PloS ONE, 10(9), 117. doi:10.1371/journal.pone.0138237

*Halvorsen, K. (1998). Impact of re-employment on psychological distress among long-term unemployed. Acta Sociologica, 41, 227-242. Gedownload van www.jstor.org/stable/4201084

Hardering, F., \& Bergheim, S. (2011). Sicherheit macht zufrieden: Wie Verunsicherung die Zufriedenheit mit der Arbeit beeinträchtigt. Gedownload van Zentrum für gesellschaftlichen Fortschritt: https://fortschrittszentrum.de/dokumente/201109_Sicherheit_macht_zufrieden.pdf

Harzing, A.-W., \& Alakangas, S. (2016). Google Scholar, Scopus and the Web of Science: A longitudinal and cross-disciplinary comparison. An International Journal for all Quantitative Aspects of the Science of Science, Communication in Science and Science Policy, 106, 787-804. doi:10.1007/s11192-015-1798-9

Henkel, D. (2011). Unemployment and substance use: A review of the literature (1990-2010). Current drug abuse reviews, 4, 4-27. doi:10.2174/1874473711104010004

Hipp, L. (2016). Insecure times? Workers' perceived job and labor market security in 23 OECD countries. Social science research, 60, 1-14. doi:10.1016/j.ssresearch.2016.04.004

Hobfoll, S.E. (1989). Conservation of resources: A new attempt at conceptualizing stress. American Psychologist, 44, 513-524. doi:10.1037/0003-066x.44.3.513

Jahoda, M. (1981). Work, employment, and unemployment: Values, theories, and approaches in social research. American Psychologist, 36, 184-191. doi:10.1037/0003-066X.36.2.184

Jahoda, M. (1995). Manifest and latent functions. In N. Nicholson (Ed.), The Blackwell encyclopedic dictionary of organizational behavior (pp. 317-318). Oxford, England: Blackwell.

Jex, S.M., \& Crossley, C.D. (2005). Organizational consequences. In J. Barling, E. K. Kelloway, \& M. R. Frone (Eds.), Handbook of work stress (pp. 575-599). Thousand Oaks, CA: Sage publications.

Kim, T.J., \& von dem Knesebeck, O. (2015). Is an insecure job better for health than having no job at all? A systematic review of studies investigating the health-related risks of both job insecurity and unemployment. Bmc Public Health, 15, 1-9. doi:10.1186/s12889-0152313-1

Kim, T.J., \& von dem Knesebeck, O. (2016). Perceived job insecurity, unemployment and depressive symptoms: A systematic review and meta-analysis of prospective 
observational studies. International Archives of Occupational and Environmental Health, 89, 561-573. doi:10.1007/s00420-015-1107-1

Koen, J., Klehe, U.C., Van Vianen, A.E.M., Zikic, J., \& Nauta, A. (2010). Job-search strategies and reemployment quality: The impact of career adaptability. Journal of Vocational Behavior, 77, 126-139. doi:10.1016/j.jvb.2010.02.004

Kroll, L.E., \& Lampert, T. (2012). Arbeitslosigkeit, prekäre Beschäftigung und Gesundheit. GBE kompakt, 3, 1-9. Gedownload van Robert Koch-Institut website: http://edoc.rki.de/

Lazarus, R.S. (1966). Psychological stress and the coping process. New York: MacGrawHill.

Lazarus, R.S., \& Folkman, S. (1984). Stress, appraisal, and coping. New York, NY: Springer.

Li, K., Rollins, J., \& Yan, E. (2018). Web of Science use in published research and review papers 1997-2017: A selective, dynamic, cross-domain, content-based analysis. Scientometrics, 115, 1-20. doi:10.1007/s11192-017-2622-5

Liberati, A., Altman, D.G., Tetzlaff, J., Mulrow, C., Gotzsche, P.C., Ioannidis, J.P.A., . . . Moher, D. (2009). The PRISMA Statement for reporting systematic reviews and metaanalyses of studies that evaluate health care interventions: Explanation and elaboration. Annals of Internal Medicine, 151(4), W65-W94. doi:10.7326/0003-4819-151-4200908180-00136

*Maggiori, C., Johnston, C.S., Krings, F., Massoudi, K., \& Rossier, J. (2013). The role of career adaptability and work conditions on general and professional well-being. Journal of Vocational Behavior, 83, 437-449. doi:10.1016/j.jvb.2013.07.001

Marchand, A., Drapeau, A., \& Beaulieu-Prevost, D. (2012). Psychological distress in Canada: The role of employment and reasons of non-employment. International Journal of Social Psychiatry, 58, 596-604. doi:10.1177/0020764011418404

McKee-Ryan, F.M., Song, Z., Wanberg, C.R., \& Kinicki, A.J. (2005). Psychological and physical well-being during unemployment: A meta-analytic study. Journal of Applied Psychology, 90, 53-76. doi:10.1037/0021-9010.90.1.53

*Mewes, R., Rief, W., Martin, A., Glaesmer, H., \& Brähler, E. (2013). Arbeitsplatzunsicherheit vs. Arbeitslosigkeit: Trotz der Unterschiede im sozioökonomischen Status sind die Auswirkungen auf psychische Gesundheit und Inanspruchnahme von Gesundheitsleistungen ähnlich. Psychotherapie Psychosomatik Medizinische Psychologie, 63, 138-144. doi:10.1055/s-0032-1332981

Otterbach, S., \& Sousa-Poza, A. (2016). Job insecurity, employability and health: An analysis for Germany across generations. Applied Economics, 48, 1303-1316. doi:10.1080/00036846.2015.1100248

*Otto, K., \& Dalbert, C. (2013). Are insecure jobs as bad for mental health and occupational commitment as unemployment? Equal threat or downward spiral. Psihološka obzorja/Horizons of Psychology, 22, 27-38. doi:10.20419/2013.22.375

Parent-Thirion, A., Biletta, I., Cabrita, J., Vargas, O., Vermeylen, G., Wilcynska, A., \& Wilkens, M. (2016). Sixth European Working Conditions Survey - Overview Report. doi:10.2806/518312

Paul, K., \& Moser, K. (2009). Unemployment impairs mental health: Meta-analyses. Journal of Vocational Behavior, 74, 264-282. doi:10.1016/j.jvb.2009.01.001

Roelfs, D.J., Shor, E., Davidson, K.W., \& Schwartz, J.E. (2011). Losing life and livelihood: A systematic review and meta-analysis of unemployment and all-cause mortality. Social Science \& Medicine, 72, 840-854. doi:10.1016/j.socscimed.2011.01.005

Roskies, E., Louis-Guerin, C., \& Fournier, C. (1993). Coping with job insecurity: How does personality make a difference? Journal of Organizational Behavior, 14, 617-630. doi:10.1002/job.4030140702 
RVA (2018). De werkloosheid in België, Duitsland, Frankrijk en Nederland volgens drie benaderingen. Gedownload van www.rva.be/nl/nieuws/de-werkloosheid-belgieduitsland-frankrijk-en-nederland-volgens-drie-benaderingen-0

Schwarz, P. (2012). Neighborhood effects of high unemployment rates: Welfare implications among different social groups. The Journal of Socio-Economics, 41(2), 180-188. doi:10.1016/j.socec.2011.12.006

Sjöberg, O. (2010). Social insurance as a collective resource: Unemployment benefits, job insecurity and subjective well-being in a comparative perspective. Social Forces, 88 , 1281-1304. doi:10.1353/sof.0.0293

*Snorradottir, A., Tomasson, K., Vilhjalmsson, R., \& Rafnsdottir, G.L. (2015). The health and well-being of bankers following downsizing: a comparison of stayers and leavers. Work Employment and Society, 29, 738-756. doi:10.1177/0950017014563106

Starrin, B., \& Janson, S. (2006). Unemployment, secure employment and insecure employment: Differences in self-reported ill health. In T. Kieselbach, A.H. Winefield, C. Boyd, \& S. Anderson (Eds.), Unemployment and Health: International and Interdisciplinary Perspectives (pp. 61-74). Bowen Hills Qld, Australia: Australian Academic Press.

Sverke, M., Hellgren, J., \& Näswall, K. (2002). No security: A meta-analysis and review of job insecurity and its consequences. Journal of Occupational Health Psychology, 7, 242264. doi:10.1037/1076-8998.7.3.242

Warr, P. (1987). Work, unemployment, and mental health. Oxford, England: Clarendon.

ii Alle referenties die in het systematisch literatuuroverzicht zijn opgenomen zijn aangeduid met een asterisk $(*)$. 


\section{Bijlage 1}

Resultaten van studies met statistische evidentie voor het verschil tussen werklozen en baanonzekeren

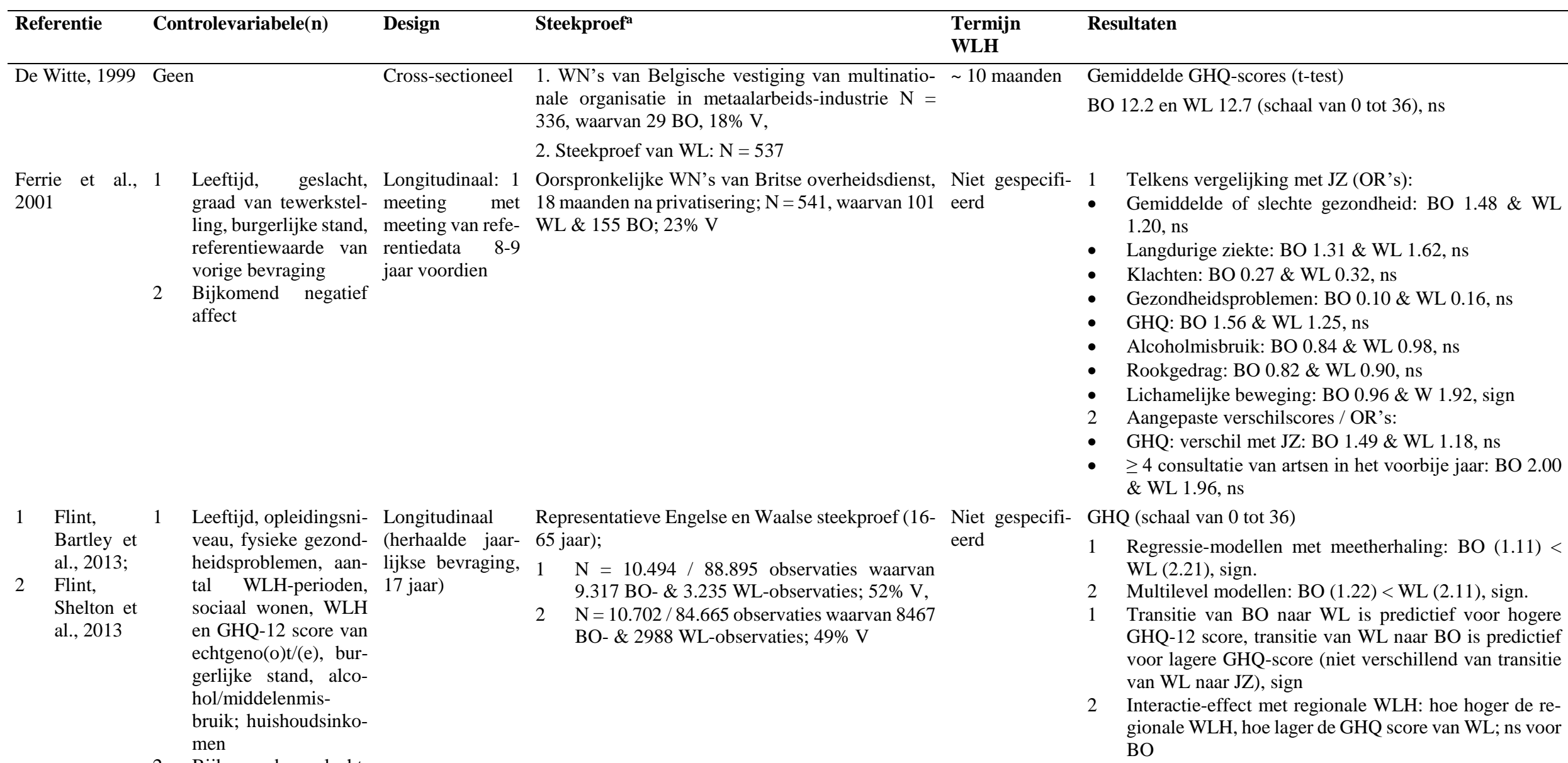

2 Bijkomend geslacht, GHQ-12 score van vorige bevraging 


\begin{tabular}{|c|c|c|c|}
\hline Referentie & Controlevariabele(n) & Design & Steekproef $^{\mathrm{a}}$ \\
\hline $\begin{array}{lll}\text { Griep } & \text { et } & \text { al., } \\
2016 & & \end{array}$ & $\begin{array}{l}\text { Geslacht, leeftijd, oplei- } \\
\text { dingsduur, burgerlijke } \\
\text { stand, kinderen, inkomen, } \\
\text { stedelijke / landelijke leef- } \\
\text { ruimte, langdurige ziekte / } \\
\text { letsel }\end{array}$ & Cross-sectioneel & $\begin{array}{l}\text { Respresentatieve Finse steekproef, 18-64 jaar } \\
\mathrm{N}=3977 \text {, waarvan } 713 \text { BO WNs (met vast con- } \\
\text { tract), } 662 \mathrm{KT}-\mathrm{WL} \& 345 \mathrm{LT}-\mathrm{WL} ; 50 \% \mathrm{~V}\end{array}$ \\
\hline
\end{tabular}

Halvorsen, Geen
1998

Halvo
1998

Longitudinaal (2 Representatieve Noorse steekproef van WL op t1, > 6 maanden metingen met af- 20-59 jaar

stand van $18 \mathrm{~N}=501$, waarvan $79 \mathrm{BO} \& 220 \mathrm{WL}, 48 \% \mathrm{~V}$

maanden)

Maggiori et al., Leeftijd, nationaliteit, taal 2013

Mewes et al., Geen

2013

Otto \& Dalbert, Leeftijd, geslacht, oplei2013 dingsniveau; persoonlijkheidskenmerken neuroticisme, extraversie, conscientieusheid maanden) $\mathrm{N}=2002$, waarvan $160 \mathrm{BO} \& 118 \mathrm{WL} ; 52 \% \mathrm{~V}$ waarvan $161 \mathrm{WL}, 218 \mathrm{BO} ; 48 \% \mathrm{~V}$

eerd

Cross-sectioneel

2. WL van 3 opleidingscentra met omscholingstrai- maanden) nings voor commerciële en IT beroepen en $30 \%$

\section{Termijn Resultaten \\ WLH}

Kortdurig (1- ANCOVA

12 maanden), langdurig $(>12$

- Psychologische klachten: BO \& langdurig WL $1.42>$ kortdurig WL 1.35, sign

- Lichamelijke klachten: langdurig WL 1.28, BO 1.27, kortdurig WL 1.25, ns

- Zelfbeoordeelde gezondheid: langdurig WL 3.74, BO 3.89, kortdurig WL 3.94, enkel langdurig vs. kortdurig WL sign

- Levenstevredenheid: langdruig WL 2.86 < kortdurig WL $3.00<$ BO 3.12, sign

Psychisch onwelzijn (depressie- en angst-items, schaal 1-4), gemiddeldes

- WL 1.43, BO 1.36, ns; ook BO = WLH betreffende verdeling verschillende scorebereiken;

- verschil van BO tussen t2 en t1 (toen ze WL waren) ns

Cross-sectioneel Representatieve steekproef uit Frans- \& Duitstalige Niet gespecifi- ANCOVAs en post-hoc analyse met Bonferroni-correctie: regio's in Zwitserland, 26-56 jaar $\quad$ eerd Levenstevredenheid: BO 4.68, WL 4.20 (schaal 1-7),

sign

- GHQ: BO 0.77, WL 0.75, ns

Cross-sectioneel Representatieve Duitse steekproef; $18-65 \mathrm{~N}=1322$, Niet gespecifi- ANOVA met post-hoc t-tests voor onafhankelijke steekproe-

ven en Bonferroni-correctie:

- $\quad$ Somatoforme symptomen: BO 3.7 en WL 3.9, schaal 0$30, \mathrm{~ns}$

- Depressieve symptomen: BO 2.9 en WL 3.6, schaal 027, ns

- $\quad$ Angstsymptomen: BO en WL 2.6, schaal 0-14, ns

- Aantal consultaties van artsen in voorbije 12 maanden: BO 6.9 en WL 7.4, ns 1. WNs van 4 organisaties en leerkrachten voor se- Kortdurig $\quad(\leq$ ANCOVAs met post-hoc vergelijkingen met Bonferroni corcundair onderwijs van Duitse provincies Nedersak- 12 maanden), rectie: Gemiddeldes, schaal 1-6:

sen en Saksen-Anhalt langdurig $(>12$ door private contacten

- Zelfwaarde: BO 4.99, kortdurig WL 5.11, langdurig WL 4.81, ns

- Levenstevredenheid: BO 4.50, kortdurig WL 4.34, langdurig WL 4.17, ns

$\mathrm{N}=334$, waarvan $97 \mathrm{WL}$ en $47 \mathrm{BO} ; 60 \% \mathrm{~V}$; 19-65 


\begin{tabular}{|c|c|c|c|c|c|}
\hline Referentie & Controlevariabele(n) & Design & Steekproef $^{\mathrm{a}}$ & $\begin{array}{l}\text { Termijn } \\
\text { WLH }\end{array}$ & Resultaten \\
\hline $\begin{array}{l}\text { Snorradottir et } \\
\text { al., } 2015\end{array}$ & $\begin{array}{l}\text { Anciënniteit, leeftijd, bur- } \\
\text { gerlijke stand; per geslacht }\end{array}$ & Cross-sectioneel & $\begin{array}{l}\text { Voormalige WNs van } 3 \text { grote banken in Ijsland die } \\
\text { door economische crisis ineenstortten; bankiers die } \\
\text { ofwel hun baan konden behouden ofwel niet; } \mathrm{N}= \\
1033 \text {, waarvan } 199 \mathrm{WL} \text { en } 431 \mathrm{BO} ; 53 \% \mathrm{~V}\end{array}$ & $\begin{array}{l}\text { Kortdurig (1-9 } \\
\text { maanden) }\end{array}$ & $\begin{array}{l}\text { Regressiecoëfficiënten met BO als referentiegroep }(\mathrm{BO}=1) \text { : } \\
\text { - } \quad \text { Positief welzijn: WL V 1.95, sign; M 2.26, sign } \\
\text { - } \quad \text { Mentaal onwelzijn (mentale symptomen): WL V 0.31, } \\
\text { sign, M 0.29, sign } \\
\text { - } \quad \text { Somatische symptomen: WL V 0.23, sign, M 0.27, sign }\end{array}$ \\
\hline
\end{tabular}

NB: Gebruikte afkortingen: $\mathrm{WL}=$ werkloos / werklozen, $\mathrm{WLH}=$ werkloosheid; $\mathrm{BO}=$ baanonzeker(en), $\mathrm{BOH}=$ baanonzekerheid; $\mathrm{WN}=$ werknemer; $\mathrm{V}=$ vrouwen, OR = Odds Ratio; sign $=$ significant $(\mathrm{p}<.05)$

a. baanonzekeren en werklozen telkens uit dezelfde steekproef tenzij anders vermeld 


\section{Comparing health and well-being of unemployed and job insecure employees: A system- atic literature review}

This study investigates whether (and to what extent) there are differences in health and wellbeing between unemployed and job insecure employees. An examination of theories results in two views: some theories predict unemployment to be more detrimental, whereas others predict both phenomena to be equally problematic for health and well-being. The aim of this study is to examine and compare both views. Therefore, this study contributes to the validation of theories (theoretical relevance) and helps determining whether policy needs to prioritize one of both phenomena (practical relevance). This systematic literature review reports on ten articles that directly compared the well-being and/or health of unemployed with that of job insecure employees. The results suggest the mental, physical, and behavioral health and well-being reactions of both groups to be similar. Only a minority of studies points towards differences, sometimes suggesting the unemployed to be worse of, and sometimes the job insecure employees. Hence, the results are mainly in line with theories that predict unemployment to be equally problematic as job insecurity, because both threaten or reduce resources. We conclude that it is equally important to reduce unemployment and its consequences as it is to reduce job insecurity and its consequences, and we suggest ways to do so.

Key words: systematic literature review, job insecurity, unemployment, health, well-being 